\title{
Students Perception towards Scaffolding Model in Reading of Junior High School
}

Muhilah Hasanah

muhillahhasanah29@gmail.com

Putri Kamalia Hakim

hakimkamaliaputri@gmail.com

\section{Universitas Singaperbangsa Karawang}

\begin{abstract}
The purpose of this study was to determine students' perceptions of the scaffolding model in reading at Mts Al-Ajhariyyah. Based on the theory of Vygotsky Scaffolding is a structured learning support technique that is carried out at an early stage to encourage students to learn independently. Qualitative descriptive research methodology. Data collection techniques are observation and interviews. The research subjects were 3 8th grade students at Mts AlAjhariyyah. Data adapted from Benedict's Thesis (2016) and Sarkol's Thesis (2016). Data analysis used thematic analysis based on Braun and Clarke (2006). The result of student perception shows that students are motivated in learning English. Discussion of the scaffolding model in reading students can be independent and active in understanding reading. Students' reactions to the Scaffolding Model in learning show that it is very influential in learning English to foster student interest in learning English. The conclusion is that using the scaffolding model is easier and more effective for students to understand English learning in exploring English skills, especially reading. The researcher's suggestion is that the use of the scaffolding model for learning English is more effective in the classroom, and helps teachers to determine learning objectives during the teaching and learning process.
\end{abstract}

Key words: Scaffolding Model; Students Perception

\section{INTRODUCTION}

Schools are an educational tool because education helps to develop and develop human potential, so secure good human resources and teaching and learning activities in schools improve the quality of education in the country. Education is an important part of life, as it is a true attempt to get it done. English is one of the subjects that must be studied in junior high school.

One of the techniques discussed in this study is reading. Reading is one of the skills students learn. Reading is one of the four difficult abilities to listening, speaking, and writing. Reading is the first ability to connect other abilities. Through reading, students gain a great deal of knowledge about all aspects of life, including culture, education, humanity, economics, business, 
politics, medical care, and technology. Reading is a keyword for getting all the information and knowledge.

On the other hand, the problem is that the reading skills of middle school students are still low, and the reading skills in school are not fully displayed. First, they were not very involved in the learning process and also tended to be noisy when learning. Second, they are cumbersome to practice, and thirdly, students are not interested in the learning process because they lack motivation. Last but not least, the majority of students dislike English subjects and English teachers. According to Wood and Ross (1976), scaffolding occurs when a more knowledgeable person helps the learner succeed in out-of-reach tasks. In addition, Chamot, Barnhardt, ElDinary, and Robbins (1994) believe that the key point of scaffolding lies in identifying the number of support students need and providing sufficient support to support student self-reliance.

In other words, expanding the previous research revealed that students had understood and could motivate themselves by not using the scaffolding method because after characterizing the concept of scaffolding and its appearances, a guiding framework will be presented that serves the purpose of analysis scaffolding but it also an organizing device for the remainder of the review. Thereafter, the descriptive studies on the effectiveness of scaffolding are examined. Finally, the major problem related to scaffolding research its measurement are explored and suggestions are made for future scaffolding research. One of the problem in this research is when students have difficulty developing creativity, organizing their ideas effectively, having difficulty composing sentences using grammar, and the students also have low motivation in learning. Therefore the researcher proposes the use of scaffolding techniques as an effective solution to solve all these problems. Scaffolding needs to be done because this assistance will help students in reading comprehension. When experiencing difficulties, students expect help from the teacher to understand the English material instead of repeating the explanation of the material. When students do not understand the teacher only re-explains the material instead of looking for ways to make students understand the material being taught. Therefore it is necessary a research was conducted to observe students abilities after being given scaffolding when students were solving problems and seeing the scaffolding stages in learning.

\section{LITERATURE REVIEW}

\section{Previous Related Study}

The scaffolding learning model is a practice based on Vygotsky's concept of assisted learning. This is a technique of providing learning support which at the initial stage is given in a more structured manner, then in sequence students' change towards independent learning. The use of scaffolding learning strategies aims to encourage students to become independent and self- regulating students. 
Scaffolding is also a teaching and learning activity that emphasizes the development of conceptual thinking skills. At this level, students get support to build, develop, and produce conceptual discourse. If students are progressing until they can achieve independence. The advantage of using the scaffolding model of learning strategy with Scaffolding model is to motivate and link students' interest with learning tasks to help students' focus on achieving goals.

\section{Students' Perception}

Perception usually consists of observations of a particular situation or environment. This general definition can be understood as the ability to see, hear feel and understand what someone is feeling about their environment, both physically and mentally. The following defines some of the crust.

Stone and Neilsen (1985:205) state that perception is an internal and external sensory-stimulated intellectual organization associated with a particular person, object, or event, whereas Leathers (1992) suggests that cognition is a cognitive process that Individuals use to interpret and understand the world around them.

This research entitled the students' perception Towards Scaffolding Model in Reading of Junior High School. The students' perception and expectation of Learning English in Junior High School furthermore are made and influenced by the student's experiences in Learning English in their own schools for at least one year Learning English. Therefore, all participants in this research are 8th students. In short, knowing the definition of perception and students' perception of the English Learning process will give an educator and learner a certain phenomenon of what students perceive about their context than can make and improve her/his Learning strategies or style in Learning to have the goal of learning.

\section{Scaffolding Techniques}

Scaffolding skills are applied by the teacher in three phases of the reading activity: the pre-reading phase, the reading phase, and the post-reading phase. This is consistent with the opinion of Gibbons (2002), who suggests that learning to read can be divided into three stages: a pre-reading stage, a reading stage, and a post-reading stage. The types of scaffolding that teachers apply to learning activities are modeling bridging, contextualising, re-presenting text, schema building, and developing metacognition.

Scaffolding aims to turn students into independent learners. To achieve this goal, scaffolding requires the teacher to first "control" the elements of the task that exceed the learner's ability. Thus, the teacher can only focus on and complete the following elements: According to Gibbons (2002), teacher support in scaffolding is "a learner's new skill, concept, or level of 
comprehension" and thus scaffolding is, according to Gibbons (2002), "a teacher helping a learner know how to do something and helping a learner later complete the same task alone 'Temporary support to help you do it.

Making students as independent learners is the purpose of scaffolding. To realize this goal, the teacher must set the material so that it becomes a difficult task for students. This is needed so that students are more focused on doing the task according to their own abilities (Wood et al). According to Gibbons (2002), teacher assistance in scaffolding is a type of temporary assistance to make students' understanding of the material presented a little more advanced. In other words, students complete the assigned tasks individually.

Gibbons (2002) revealed that there are three sequences of teacher assistance in the context of reading, they are:

1. Before reading: the teacher will teach students about difficult words and then tell the translation of the words.

2. During reading: the teacher will tell students about how to complete the given task such as conducting group discussions, using media, and others.

3. After reading: the teacher engages students in the conversation in the reading text, asks them to answer the questions provided, then asks them to determine the essence of the reading text and conclude it.

\section{Teaching by using Scaffolding}

According to Vygotsky (1978), mention that learning leads to development. While this idea does not ignore the notion that the educational experience completely exceeds the learner's ability, it challenges the notion of "preparation" of learning by suggesting that the primary responsibility for initiating each new stage of learning is the teacher. It builds on what the learner is currently alone. It maintains the high expectations of all students and requires teachers to provide an adequate foothold for the successful completion of tasks. When properly applied, scaffolding offers several advantages to teaching in the classroom, including engaging students in activities, motivating students to learn more, and relieving students of stress during class (Van Der Stuyf, 2002). Thus, scaffolding can motivate students to engage in reading activities. When properly applied, scaffolding offers several advantages to teaching in the classroom, including engaging students in activities, motivating students to learn more, and relieving students of stress during class (Van Der Stuyf, 2002). Thus, scaffolding can motivate students to engage in reading activities.

Scaffolding as a teaching strategy relies heavily on the idea that children come to an educational environment with a lot of existing knowledge, some of which may be incorrect. Making scaffolding an effective teaching method is a process that builds on what students already know. Maybin, Mercer, and Steirer (1992: 186, quoted Hammond 2009: 3) explain "Scaffolding as the 
temporary but essential nature of the mentors' assistance in helping students to do the tasks successfully". From what experts state, scaffolding is the support and support of teachers so that they can learn in the classroom, and many teachers and teachers should do this for their students.

\section{METHOD}

\section{Design and Samples}

This research uses descriptive qualitative research method. In this study, this study selected three students in one of the 8th grade at Mts Al-Ajhariyyah. The sampling technique was purposive sampling, based on purposive sampling, namely a non-probability sampling technique, where the ease of accessibility and proximity to the researcher became the benchmark in selecting participants. The author in this study carried out the scaffolding technique to teach reading in junior high school after obtaining permission from the school, so the scaffolding model was used for the method of learning English at Mts Al-Ajhariyyah.

\section{Instrument and Procedure}

In collecting data, researchers used interviews and observations. Therefore, this research was assisted with observation guide instruments, interviews, recording devices, and writing instruments. There are 14 core questions asked in the interview section and 12 core questions asked in the observation section because the instrument is something that has a very important position. And the steps of this research start from (1) planning, (2) implementation, (3) data collection after researchers apply the Scaffolding method to students, and (4) conclusions, researchers describe the results of the data obtained from the questionnaire used as secondary data and used to confirm primary data from interviews and data from interviews recorded using a voice recorder to process data easily and then transcribed.

\section{Data Analysis}

The researchers conducted an analysis of questionnaires and interviews using the thematic analysis framework developed by Braun \& Clarke (2006) as quoted in (Heriyanto, 2018).

\section{RESULT AND DISUSSION}

This study presents findings and discussion of research. The findings of the research covers the analysis of Students Perception in the use scaffolding 
model in Reading and the material about the narrative text at Mts AlAjhariyyah.

\section{Scaffolding Makes The Learning More Enjoyable For The Students'}

The researcher gave a scaffolding model to the students' conversation because it aimed to increase interest in learning English so that the teaching and learning process of English in reading went well because previous research explained the teacher's perception when implementing the scaffolding strategy, therefore the researcher re-applied the scaffolding model related or not with previous research. The researcher used six main types of scaffolding in teaching reading, based on what was identified by Walqui (2006), such as: Modeling where the teacher uses verbal explanation and body language with elaborates and demonstrates the new material, bridging where students activate prior knowledge, contextualizing which can be offered in various forms, schema the building that can be defined as clusters of meaning that are organized, re-presenting text, making the students engage in the task which needs language transformation in a different text genre and interconnected developing metacognition that refers to learner awareness of their own knowledge and their ability to understand, control and monitor their level of understanding and manage their thinking process in other to decide when it is adequate. Based on the interview, the researcher ask the student "Do students like learning to read with the Scaffolding Model that has been done by the researcher?" and the student answer:

"Iya ka saya menyukainya, karna lebih seru diskusi bareng-bareng temen juga" $\{p 1\}$

"Suka ka, karena membaca itu kan mudah jadi materinya mudah dipahamin" $\{p 2\}$

"Iya suka ka, berdiskusi bareng dengan teman-teman, saling rebut jawaban ketika ada yang bertanya” $\{p 3\}$

The data concerns how the students felt when learning reading using Scaffolding Model. Then, all students felt that scaffolding could make it easier for them to understand the reading of the narrative text. The same response was also shown by students who thought that scaffolding could improve their reading skills and be the right reading method used by teachers in teaching reading because students prefer to interact in groups and can sharing knowledge with their classmates. This finding is in line with the result of a study by Abdul-Majeed and Muhammad (2015) which showed that scaffolding was effective to develop the students' reading skills as they could understand more about the use of different reading strategies.

\section{Scaffolding Makes Students' More Motivated}

Similar results were also revealed here that students understood so much that they liked that the use of scaffolding made it easier for them to find the 
main idea, detailed information, and the whole of the material that had been presented by the researcher.

"Iya ka saya memahami akan tetapi saya kurang fasih untuk belajar bahasa inggris" $\{p 1\}$

"iya ka sangat memahami karena belajarnya sambil bercerita” $\{p 2\}$

"Iyya ka saya paham karena materi nya tentang bercerita-cerita jadi termotivasi untuk lebih mendalami belajar inggris" $\{p 3\}$

This finding shows that Mts Al-Ajhariyyah students are already excited to learn to read through the application of scaffolding in the classroom, which is revealed from the responses of students in class. Almost all of them show a sense of enthusiasm and confidence to carry out classroom learning if the teacher teaches reading using scaffolding in the classroom. In the interview, they revealed that they enjoy learning English but there are some who are unable to pronounce certain sentences in English. They said that they needed more time to study apart from in class. Motivation plays the main role in all aspects to have the goal of learning. Without having good motivation, the better goal of learning is impossible to have. The motivation can be external motivation such as the method used by the teacher in teaching, the student family, to whom the student makes a friend, and so on, while internal motivation furthermore can be something hoped by the student but however it absolutely influenced the environment of the student. In another word, it is not depended on how the situation is but its dependent on how the student himself or herself feel of the study.

\section{Scaffolding Fits The Students Studying Pace}

The advantages use Scaffolding Model from Gabriel Peters (2020) such as:

a. Involving the students

Through scaffolding, students are involved in an active learning process. The teacher builds on the knowledge that students have about a particular topic. Scaffolding is like a research assignment where students are made to find solutions to unanswered questions. It motivates the learner and gives him the impetus to learn more.

b. Minimize the tension in learning when afraid to have an opinion

Scaffolding minimizes student frustration levels. This can be used to "calm" students who are easily frustrated when studying with their peers. The learner's behavior can be monitored, and time can be used to advise him on the frustration he builds up while studying with others in the same class.

c. Study Anytime

By learning anytime, students can learn with the activities that students do and learn at the student's pace. English material which includes teac hing and learning basic skills such as speaking, listening and writing. 
Scaffolding can be disadvantageous for teachers, because it necessitates giving up control to allow learners to learn at their own pace. It is also time-consuming, on certain occasions, the teacher may be forced to cut short the time allocated for each student in order to accommodate all learners. This can result in frustration, and the students' urge to learn can slowly fade.

Based on the observation, the students can understand the learning carried out by researchers and students can be motivated to learn English then the students can get used to learning English outside school hours by reading English texts or repeating material about narrative texts that have been given to researchers to understand every vocabulary in the text and students are enthusiastic to understand the vocabulary. The results of the observation data are following what happened to students and teachers at the MTS AlAjhariyyah school.

\section{Scaffolding Makes Silent Students More Engaged In The Discussion.}

The result of data collection by researchers through observation and interviews is the perception of students who are motivated to learn English in learning is discussion. Thus, the discussion is a great way to check understanding when students are reading a difficult piece of text or learning a new concept. teachers need to design learning materials, ensure that students can feel when learning using the scaffolding model, Maintain student involvement as active listeners by asking someone to provide a gist of what has just been discussed, discovered, or questioned. Scaffolding Model a method for learning in the classroom for students. and the results obtained from interviews and observations finally showed positive results for students when using the Scaffolding Model such as having a much greater quality and much more beneficial experience for all involved.

Researchers in this study used a scaffolding model to help students develop the meaning contained in the reading text so that students more easily understand the content of the reading. The researcher makes his thoughts explicit by expressing his thoughts when reading orally and also the researcher wants if students can know the meaning of the text and can understand the text. From the description above, the researcher has an analysis that occurs in the classroom during the learning process. The researcher translates some words that are difficult for students to know or words that are not known to students one by one before starting to read the text and the reasons students find it easier to know the context of the reading can facilitate the learning process. based on the observation of the researcher's data that whether students are appreciated by the teacher, it is appropriate that the researcher uses the scaffolding model that is applied in the classroom that can be felt by students when learning English learning with the media that has been provided. 


\section{CONCLUSION}

Based on the result of the data analysis and the findings in the previous chapter. The researcher found the results of his research on student perceptions of how students feel when using the scaffolding model in learning English reading. samples of students' perceptions Scaffolding makes it more fun, researchers apply a scaffolding model in reading narrative texts aimed at growing students' interest in learning English in reading so that students do not depend on teachers or supervisors in class and this scaffolding model can be done outside the classroom during students' free time who increase their demand to learn English, they can express their English learning outside class or outside class hours. Scaffolding Model in reading results that students are in accordance with their learning abilities, students who are able to accommodate the material provided by researchers and even students who are ready when asked by researchers about narrative text material, slowly students become strong in understanding the material. Then scaffolding makes students who are silent become involved in the class to provide information in the discussion. In addition, the discussion is a great way to check comprehension when students are reading texts that are difficult to learn new concepts because teachers need to design learning materials, ensure that students can feel when learning using the scaffolding model, Maintain student engagement as active listeners by asking someone to provide digests of what was recently discussed, discovered, or questioned.

\section{REFERENCES}

Gibbons, Pauline. (2002). Scaffolding Language, Scaffolding Learners: Teaching Second Language Learners in the Mainstream Classroom. Portsmouth:Heinemann.

Leather, D.G. (1992) Successful on Verbal Communication, Principle and Application. Massachusetts: Addison Wesley Publishing Company.

Mart, Ç.T. (2012). Developing speaking skills through reading. International Journal of English Linguistics, 2 (6), 91-96.

Roehler, L. R. \& Cantlon, D. J. (1996).Scaffolding: A Powerful Tool in Social

Constructivist Classroom. Michigan:Michigan States University.

Stone and nielsen (1985), educational phychology: the development of teaching skills. Massachusetts: Addison Wesley Publishing Company.

Wood, D., Bruner, J.S., \& Ross, G. (1976). The role of tutoring in problem solving.Journal of Child Psychology and Psychiatry, 17, 89-100

Vygotsky LS (1978) Mind in society: the development of higher psychological processes. Harvard University Press, Cambridge, M

Van Der Stuyf, R. R. (2002). Scaffolding as a teaching strategy. Adolescent learning and development, 52(3), 5-18. 